\title{
STRATEGI MARKETING HOTEL ROYAL KUNINGAN JAKARTA PADA MASA COVID-19
}

\author{
Helen Olivia, M.Ikom \\ Universitas Satya Negara Indonesia, helenolivia.fisip@gmail.com
}

\begin{abstract}
Abstrak
Abstrak - Penelitian ini membahas tentang strategi marketing Hotel royal Kuningan pada masa Covid-19. Tujuan dari penelitian ini adalah untuk mendeskripsikan pelaksanaan strategi marketing pada masa Covid-19. Teori yang digunakan adalah Marketing Mix 7P (Product, Price, Place, Promotion, People, Physical Evidence, Process). Paradigma yang digunakan adalah konstruktivisme dengan pendekatan penelitian kualitatif. Metode yang digunakan adalah studi kasus. Subjek penelitian dalam penelitian ini terdiri dari informan kunci dan informan. Teknik pengumpulan data menggunakan wawancara mendalam. Hasil penelitian ini menunjukkan bahwa strategi marketing yang digunakan adalah disesuaikan dengan protocol kesehatan yang sudah ditetapkan sehingga marketing mix 7P (Melakukan promosi Sales Call Door to Door dan memanfaatkan website) sangat bermanfaat bagi keberlangsungan operasional Hotel Royal Kuningan khususnya.
\end{abstract}

Kata Kunci: Strategi Marketing, Marketing Mix, Covid-19

\begin{abstract}
Abstract - This research discusses the marketing strategy of the Royal Kuningan Hotel during the Covid-19 period. The purpose of this study is to describe the implementation of a marketing strategy during the Covid-19 period. The theory used is the 7P Marketing Mix (Product, Price, Place, Promotion, People, Physical Evidence, Process). The paradigm used is constructivism with a qualitative research approach. The method used is a case study. The research subjects in this study consisted of key informants and informants. Data collection techniques using in-depth interviews. The results of this study indicate that the marketing strategy used is adjusted to the established health protocols so that the 7P marketing mix (Doing Door to Door Sales Promotion and utilizing the website) is very beneficial for the operational sustainability of Hotel Royal Kuningan in particular.
\end{abstract}

Keywords: Marketing Strategy, Marketing Mix, Covid-19

\section{PENDAHULUAN}

Januari 2020 Organisasi Kesehatan Dunia (WHO) mengumumkan wabah penyakit corona virus baru di Provinsi Hubei, Tiongkok menjadi Darurat Kesehatan Publik untuk Kepedulian Internasional. WHO menyatakan ada risiko tinggi penyakit coronavirus 2019 (COVID-19) menyebar ke negara lain di seluruh dunia. WHO dan otoritas kesehatan publik di seluruh dunia mengambil tindakan untuk mengendalikan wabah COVID-19. Namun, kesuksesan jangka panjang tidak bisa diterima begitu saja. Semua bagian masyarakat kita - termasuk bisnis dan pengusaha- harus berperan jika kita ingin menghentikan penyebaran penyakit ini (WHO.Int di unggah pada tanggal 3 Maret 2020).
Dapat dipahami bahwa COVID-19 sudah banyak membawa kerugian di seluruh sektor dan bukan hanya sektor kesehatan saja, menurut WHO Semua negara harus mencapai keseimbangan yang baik antara melindungi kesehatan, meminimalkan gangguan ekonomi dan sosial, dan menghormati hak asasi manusia (WHO.Int di unggah pada tanggal 11 maret 2020).

WHO menyatakan bahwa COVID-19 ini bukan hanya krisis kesehatan masyarakat, ini adalah krisis yang akan menyentuh setiap sektor sehingga setiap sektor dan setiap individu harus terlibat dalam perjuangan. Negara-negara harus mengambil pendekatan seluruh pemerintah, seluruh masyarakat, dibangun di sekitar strategi komprehensif untuk mencegah infeksi, menyelamatkan 
nyawa dan meminimalkan dampak (WHO.Int di unggah tanggal 11 Maret 2020).

Semua perusahaan baik yang bergerak dalam bidang jasa maupun penyiapan produk pasti memiliki tujuan untuk tetap berkembang dan berjalan dengan baik untuk dapat mempertahankan dan meningkatkan keuntungan atau laba operasional perusahaan. Hal ini dapat dilakukan apabila perusahaan mampu mempertahankan dan meningkatkan penjualan produk atau jasa yang mereka hasilkan. Dengan menerapkan strategi pemasaran yang efektif melalui pemanfaatan peluang yang ada untuk meningkatkan penjualan diharapkan dapat mempertahankan dan meningkatkan posisi perusahaan di pasar. Pelaksanaan strategi pemasaran saat ini sangat penting untuk mendukung peningkatan laba.

Dalam masa pandemik wabah Covid 19 ini strategi pemasaran merupakan hal yang sangat penting untuk di lakukan. Untuk memperoleh hasil yang optimal, strategi pemasaran mempunyai ruang lingkup yang luas antara lain strategi dalam menghadapi persaingan, strategi harga, strategi produk, strategi pelayanan dan sebagainya.

Hotel Royal Kuningan merupakan salah satu hotel yang berada di daerah Kuningan Jakarta Selatan yang memiliki fasilitas yang sangat memadai untuk dijadikan pilihan berkunjung apalagi hotel ini merupakan Hotel Bintang 4 (empat).

Di tengah pandemi wabah Covid 19 hotel bintang 4 (empat) ini mengalami penuruan okupansi dikarenakan adanya social distancing, pemberlakuan PPKM (Pemberlakuan Pembatasan Kegiatan Masyarakat) serta penurunan minat pengunjung untuk datang berkunjung.

Berdasarkan latar belakang diatas perlu adanya strategi marketing untuk mengatasi permasalahan yang terjadi pada masa Covid19 ini. Maka penulis tertarik untuk melakukan penelitian dengan judul Strategi Marketing Hotel Royal Kuningan Pada Masa Covid-19. Sedangkan tujuan penelitian adalah Untuk mendeskripsikan strategi marketing yang digunakan Hotel Royal Kuningan Pada Masa Covid-19.

\section{KAJIAN LITERATUR Pemasaran}

Pemasaran merupakan kegiatan penting dalam perusahaan yang ditujukan untuk memenuhi kebutuhan dan keinginan masyarakat melalui suatu produk yang diharapkan dapat memberikan manfaat bagi konsumen, selain itu pemasaran ditujukan untuk meningkatkan keuntungan bagi perusahaan. Menurut Kotler dan Keller (2016: 27) marketing is a societal process by which individuals and groups obtain what they need and want through creating, offering, and freely exchanging products and services of value with others.

\section{Marketing Mix}

Menurut Kotler dan Amstrong (2016: 51) pengertian bauran pemasaran (marketing mix) adalah marketing mix is the set of tactical marketing tools that the firm blends to produce the response it wans in target markets.

Adapun pengertian $7 \mathrm{P}$ menurut Kotler dan Amstrong (2016: 62) sebagai berikut: 1. Produk (product) adalah mengelola unsur produk termasuk perencanaan dan pengembangan produk atau jasa yang tepat untuk dipasarkan dengan mengubah produk atau jasa yang ada dengan menambah dan mengambil tindakan yang lain yang mempengaruhi bermacam-macam produk atau jasa. 2. Harga (price) adalah suatu sistem manajemen perusahaan yang akan menentukan harga dasar yang tepat bagi produk atau jasa dan harus menentukan strategi yang menyangkut potongan harga, pembayaran ongkos angkut dan berbagai variabel yang bersangkutan. 3. Distribusi (place) yakni memilih dan mengelola saluran perdagangan yang dipakai untuk menyalurkan produk atau jasa dan juga untuk melayani pasar sasaran, serta mengembangkan sistem distribusi untuk pengirim dan perniagaan produk secara fisik. 4. Promosi (promotion) adalah suatu yang digunakan untuk memberitahukan dan membujuk pasar tentang produk atau jasa yang baru pada perusahaan melalui iklan, penjualan pribadi, promosi penjualan, maupun publikasi. 5. Orang (People) adalah semua pelaku yang memainkan peranan penting dalam penyajian jasa sehingga dapat mempengaruhi persepsi pembeli. Elemen dari orang adalah pegawai perusahaan, konsumen, dan konsumen lain. Semua sikap dan tindakan karyawan, cara berpakaian karyawan dan penampilan karyawan memiliki pengaruh terhadap keberhasilan penyampaian jasa. 6. Fasilitas Fisik (Physical Evidence) merupakan hal nyata yang turut mempengaruhi keputusan konsumen untuk membeli dan menggunakan 
produk atau jasa yang ditawarkan. Unsur yang termasuk dalam sarana fisik antara lain lingkungan atau bangunan fisik, peralatan, perlengkapan, logo, warna dan barang-barang lainnya. 7. Proses (process) adalah semua prosedur aktual, mekanisme, dan aliran aktivitas yang digunakan untuk menyampaikan jasa.

\section{METODOLOGI PENELITIAN}

Paradigma yang digunakan dalam penelitian ini adalah paradigma konstruktivistik. Paradigma konstruktivis adalah paradigma yang melihat realitas sosial sebagai konstruksi sosial yang diciptakan oleh individu, yang merupakan manusia bebas. Individu menjadi penentu dalam dunia sosial yang dikonstruksi berdasarkan kehendaknya, yang dalam banyak hal memiliki kebebasan untuk bertindak di luar batas kontrol struktur dan pranata sosialnya. Paradigma ini memandang ilmu sosial sebagai analisis sistematis terhadap socially meaningful action melalui pengamatan langsung dan terperinci terhadap pelaku sosial yang bersangkutan menciptakan dan memelihara atau mengelola dunia sosial mereka (Dedy N, Hidayat, 2003).

Metode Penelitian yang digunakan dalam penelitian ini yaitu studi kasus. Menurut Mulyana (2013:201) studi kasus adalah uraian dan penjelasan komprehensif mengenai berbagai aspek seorang individu, suatu kelompok, suatu organisasi (komunitas), suatu program, atau situasi sosial. Dengan menggunakan metode studi kasus maka peneliti berupaya menelaah sebanyak mungkin data mengenai subjek yang diteliti dengan menggunakan berbagai metode, seperti wawancara, pengamatan, dan dokumentasi. Dalam penelitian ini peneliti tidak lupa untuk membuat suatu batasan penelitian agar tidak terlalu meluas dan tetap fokus.

\section{Key Informan dan informant}

Key Informan yang telah memenuhi kriteria diatas adalah Direktur Marketing Hotel Royal Kuningan Ibu Ria Fazryanti. Sedangkan informantnya adalah staf front office Hotel Royal Kuningan Bapak Ahmad Ismail.
Teknik Pengumpulan Data

Berdasarkan sumber datanya, pengumpulan data dapat menggunakan sumber primer dan sumber sekunder. Teknik pengumpulan data primer pada penelitian ini dilakukan melalui wawancara mendalam dan observasi. Sementara itu, data sekunder penelitian ini diperoleh melalui studi literatur dan dokumentasi.

\section{Teknik Keabsahan Data}

Menurut Moleong (2008:326-332) agar hasil penelitian dapat dipertanggung jawabkan maka diperlukan pengecekan data apakah data yang disajikan valid atau tidak, maka diperlukan teknik keabsahan/kevalidan data. Untuk memeriksa keabsahan data dalam penelitian ini, peneliti menggunakan teknik triangulasi. Menurut Sugiyono (2013:330) triangulasi diartikan sebagai teknik pengumpulan data yang bersifat menggabungkan data dari berbagai teknik pengumpulan data dan sumber data yang telah ada.

Untuk mengukur keabsahan data, ada berbagai teknik pemeriksaan data salah satunya adalah Triangulasi data. Triangulasi merupakan suatu proses untuk menentukan aspek validitas informasi yang diperoleh, kemudian disusun dalam suatu penelitian. Dalam penelitian ini, peneliti memilih menggunakan metode Triangulasi sumber. Menurut Sugiyono (2013:330) triangulasi sumber berarti untuk mendapatkan data dari sumber yang berbeda-beda dengan teknik yang sama

\section{Teknik Analisis Data}

Setelah mendapatkan data yang diperoleh melalui observasi, wawancara dan dokumentasi maka tahap selanjutnya adalah melakukan analisis data. Analisis data dalam penelitian kualitatif dilakukan sejak sebelum memasuki lapangan, selama di lapangan dan setelah selesai di lapangan. Analisis data yang akan dilakukan menggunakan versi Miles dan Huberman, dalam Sugiyono (2013:337) bahwa aktivitas dalam analisis data kualitatif dilakukan secara interaktif dan berlangsung secara terus-menerus sampai tuntas sehingga datanya jenuh. Aktivitasnya meliputi reduksi 
data (data reduction), penyajian data (data display) dan penarikan kesimpulan.

\section{PEMBAHASAN}

Hotel Royal Kuningan pada dasarnya adalah rencana yang menyeluruh, terpadu dan menyatu di bidang pemasaran yang memberikan panduan tentang kegiatan yang akan dijalankan untuk dapat tercapainya tujuan pemasaran suatu perusahaan. Strategi pemasaran diperlukan bagi industri perhotelan yang berorientasi pada fungsi profit. Saat ini seluruh dunia sedang di landa oleh Wabah Covid 19 dan membawa dampak terhadap seluruh aspek kehidupan. Kemunculan virus corona ini membuat banyak orang menjadi takut melakukan aktivitas keluar rumah. Mereka cenderung melakukan penundaan atau bahkan hingga pembatalan. Pemerintah juga sudah mengeluarkan peraturan untuk mengantisispasi penyebaran Covid 19, dengan mengurangi pergerakan orang-orang. Seiring dengan hal tersebut setiap perusahaan harus melakukan antisipasi dengan menyesuaikan dengan peraturan pemerintah tetapi juga harus konsentrasi terhadap target perusahaan. Dengan menerapkan strategi pemasaran yang efektif melalui pemanfaatan peluang yang ada untuk meningkatkan penjualan diharapkan dapat mempertahankan dan meningkatkan posisi perusahaan di pasar. Pelaksanaan strategi pemasaran saat ini sangat penting untuk mendukung peningkatan laba. Untuk memperoleh hasil yang optimal, strategi pemasaran mempunyai ruang lingkup yang luas antara lain strategi dalam menghadapi persaingan, strategi harga, strategi produk, distribusi, promosi, orang, fasilitas fisik dan proses. Demi strategi pemasaran yang diterapkan demi hasil yang efektif dalam memiliki kesempatan yang ada untuk peningkatan penjualan diharapkan dapat mempertahankan dan meningkatkan posisi perusahaan di pasar. Pelaksanaan strategi pemasaran saat ini sangat penting untuk mendukung peningkatan laba. Hotel Royal Kuningan saat ini membuat starategi bagaimana tetap memperoleh revenue dengan hanya mengandalkan dari okupansi kamar dan meeting room sebagai berikut:

1. Strategi Produk. Penerapan strategi produk yang dilakukan adalah dengan memastikan kebersihan kamar kemudian memberikan pelayanan kepada tamu dengan hati, sigap, cepat dan tanggap. Sedangkan meeting room dibatasin maksimal hanya 200 pax, sehingga tim marketing menawarkan gedung untuk kenyamanan para tamu yang datang.

2. Strategi Harga yang dipakai adalah penyesuaian dengan kondisi Covid-19, Hotel Royal Kuningan ingin memperkenalkan produk tanpa adanya koreksi harga dari masyarakat. Penurunan harga kamar sebanyak $50 \%$. kepada tamu dimulai dari Rp. 650.000/malam untuk Garuda Duluxe, Rp 850.000/malam untuk Executive, Rp. 900.000/malam untuk Heritage dan Rp. 950.000/malam untuk Premier. Untuk sarapan yang semula buffet menjadi mealbox seharga Rp. 60.500/box.

3. Distribusi. Lokasi Royal Kuningan ini sangat strategis di daerah Kuningan yang mana Kuningan Jakarta ini adalah segitiga kota Jakarta dan Pusat para Pebisnis untuk melakukan bisnis, kemudian posisi Royal Kuningan berdampingan dengan Kantor Kementerian dimana terdiri dari Kantor KPK, Kementerian Kesehatan dan Kementerian Ketenagakerjaan.

4. Strategi Promosi. Promosi yang dilakukan adalah melalui Website ; www.royalkuningan.com. Selain itu tim marketing dari Royal Kuningan juga melakukan Sales Call Door to Door ke Kantor Pemerintahan menawarkan meeting room dan kamar.

5. Strategi Orang. Hotel Royal Kuningan memiliki tim marketing serta karyawan dari Divisi lain yang mendukung kenaikan profit. Dimasa Pandemi Covid-19 ini ada pengurangan karyawan yang awalnya berjumlah 30 orang karyawan menjadi 8 orang karyawan. Sehingga ada pembatasan kehadiran.

6. Fasilitas Fisik. Hotel Royal Kuningan memiliki kolam renang yang mencolok karena berada dilantai 1 (satu) yang mempunyai pemandangan yang bagus, serta kamar yang bertemakan klasik tapi tidak memberikan kesan yang tidak klasik, memiliki ruangan berkapasitas 1500 orang untuk standing, 
mempunyai lobi yang berada dilantai 1 (satu) yang berbeda dengan hotel yang lain.

7. Strategi proses. Proses yang dijalankan oleh Royal Kuningan adalah dengan menerapkan standar yang berlaku, khususnya kondisi Pandemi COvid -19 yang secara keseluruhan menggunakan standar Protokol Kesehatan.

\section{KESIMPULAN}

Strategi pemasaran yang dilakukan oleh Hotel Royal Kuningan dalam situasi Pandemi Covid 19 adalah dengan memanfaatkan fasilitas Hotel untuk berkeasi dan berinovasi dalam situasi ini serta melakukan promosi sales call door to door dan memanfaatkan website sebagai sarana informasi kepada masyarakat. Strategi yang dipakai memberikan manfaat bagi eksistensi Hotel Royal Kuningan. Dalam situasi ini diharapkan menghasilkan sesuatu yang baru untuk meningkatkan revenue hotel dan jumlah pengunjung. Walaupun target perusahaan terpenuhi $100 \%$ setidaknya dalam kondisi pandemic Covid 19 Hotel Royal Kuningan dapat berkontribusi memenuhi kebutuhan masyarakat.

\section{REFERENSI}

Dedy N, Hidayat, Paradigma Dan Metodologi Penelitian Sosial Empirik Klasik (Jakarta: Departemen Ilmu Komunikasi FISIP Universitas Indonesia, 2003)

Fera Indasari, Ida Anggriani, 'Krisis

Komunikasi Pada Masa Pandemi Covid19 (Studi Kasus Pemberitaan Penyebaran Covid-19 Melalui Udara)', Jurnal Professional FIS UNIVED, 7.No.1 (2020)

Kotler, Philip and Gary Amstrong, 'PrinsipPrinsip Pemasaran', in Prinsip-Prinsip Pemasaran (Jakarta: Erlangga, 2016), p. 27

— Prinsip-Prinsip Pemasaran (Jakarta: Erlangga, 2016), p. 51

_ 'Prinsip-Prinsip Pemasaran', in Prinsip-Prinsip Pemasaran (Jakarta: Erlangga, 2016), p. 62

Lexy, J Moleong, Metodologi Penelitian Kualitatif (Bandung: PT Remaja Rosdakarya, 2008)

Mulyana, Deddy, Metode Penelitian Kualitatif (Bandung: PT Remaja Rosdakarya,
2013)

Sugiyono, Metode Penelitian Pendidikan Pendekatan Kuantitatif, Kualitatif, Dan $R \& D$ (Bandung: Alfabeta, 2013)

_, 'Metode Penelitian Pendidikan Pendekatan Kuantitatif, Kualitatif, Dan R\&D', in Metode Penelitian Pendidikan Pendekatan Kuantitatif, Kualitatif, Dan $R \& D$ (Bandung: Alfabeta, 2013), p. 337

\section{BIODATA PENULIS}

Helen Olivia, S.Ikom., M.Ikom adalah dosen di Universitas Satya Negara Indonesia. Menyelesaikan jenjang pendidikan Strata Satu (S1) di Universitas Prof. Dr. Moestopo (B) Jakarta Tahun 2007. Fakultas Ilmu Komunikasi Jurusan Ilmu Komunikasi (Humas) dan menyelesaikan Strata Dua (S2) Magister Komunikasi Korporat Tahun 2012. Selain aktif mengajar juga aktif sebagai narasumber PR, moderator, MC untuk kegiatan seminar politik komunikasi, menghandle event dan peneliti komunikasi. 